\title{
Preservation of a Textile Culture Through a Digital Cultural Heritage
}

\author{
Fehmiye Dilek Himam Er*, Ender Yazgan Bulgun, Elvan Özkavruk Adanır \\ Faculty of Fine Arts and Design, Department of Fashion and Textile Design, İzmir University of Economics, İzmir, Turkey \\ Email address: \\ dilek.himam@ieu.edu.tr(F.D.HimamEr), ender.bulgun@ieu.edu.tr(E.Y.Bulgun), elvan.ozkavruk@ieu.edu.tr(E. Ö.Adanır) \\ ${ }^{*}$ Corresponding author
}

\section{To cite this article:}

Fehmiye Dilek Himam Er, Ender Yazgan Bulgun, Elvan Özkavruk Adanır. Preservation of a Textile Culture Through a Digital Cultural Heritage. International Journal of Science, Technology and Society. Vol. 6, No. 2, 2018, pp. 25-32. doi: 10.11648/j.ijsts.20180602.11

Received: March 1, 2018; Accepted: March 23, 2018; Published: May 8, 2018

\begin{abstract}
This study will directly address an overview of digitalization practices on how Sümerbank fabric archive could add value to the preservation, protection and of Turkish textile cultural heritage. Sümerbank was one of the state-centered institutions, which was producing affordable printed cotton textile products in Turkey between the years of 1930-2000s. In this study, 6600 Sümerbank textile patterns which is produced between years of 1956-2001 had been digitized and built a website to create a network between researchers, designers, governmental and private institutions.
\end{abstract}

Keywords: Digital Design Archive, Printed Fabrics, Cultural Heritage, Sumerbank

\section{Introduction}

With the establishment of Turkish republic, the ordinances taking after İzmir Economic Congress of 1923, gave way for the development of weaving industry in Turkey. Transfer of administrations of Feshane, Hereke and Bakırköy factories left from Ottoman Empire in 1925 to Sanayii Maadin Bankası, old factories had been obtained footing and provided opportunity with the new modernization techniques. However, the first modern production had been started after the establishment of Sümerbank in 1933 with the effect of President Mustafa Kemal Atatürk's decision during İzmir Economic Congress. The factories of Sanayii Maadin Bankasl transferred to Sumerbank.

Sumerbank which has great importance within the Turkish industrial revolution had been emerged a national and collective identity among the society. Textile industry of the country had been started to protect by Sumerbank and its factories initially contributed to the nation-state building project by means of producing affordable textile products. These were made of local cotton fabrics like basma (calico), poplin, pazen (flannel) or wool fabrics as well as carpets, threads, shoes and other household textiles.
Sumerbank also aimed to look after the financing, construction and operation of such diverse products as steel, paper, rayon, ceramics, caustic soda, chlorine and cement. In time, they developed into schools where textile designers were trained not only to adapt world fashion into Turkish style but also to produce numerous fabric patterns. In spite of their limited colour range due to the economic conditions, these fabrics led to the development of a national textile design style creating "a Sümerbank material culture in Turkey by introducing its own fabrics and distinctive designs" [1]. Sumerbank factories opened almost on every city of the country were considering as gatedcomnutities teaching how to behave, how to be civilized modern individual and how to use Republican idealizatins to Sümerbank generation. Sumerbank while covering the textile demands of the country became a cultural symbol in Turkish textile cultural heritage. (See Figure 1). In sum, Sumerbank as one of the most important state-centered establishment of Turkish Republic had became a symbolic name of the history of Turkish economy and textile for more than 70 years starting from 1930s. 


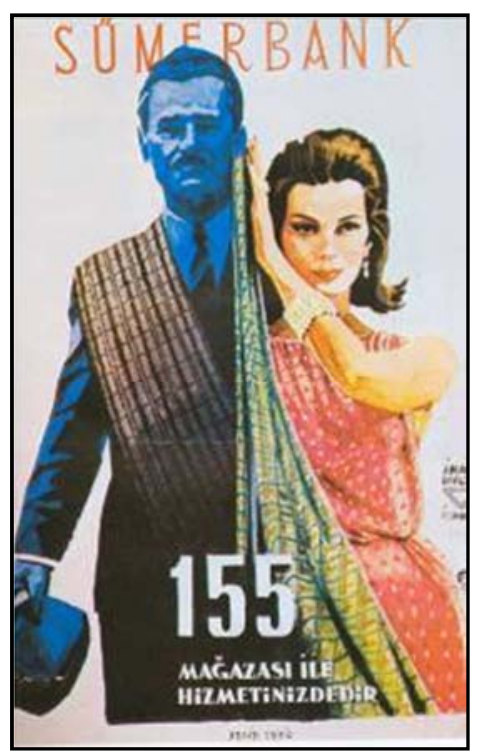

Figure 1. Sümerbank poster produced by İhap Hulusi (Ömer Durmaz Archive).

\section{Sümerbank Textile Culture in Turkey}

Sümerbank founded in July 11, 1933 had three main periods; establishment and development years (1933-1950); maturity stage (1950-1972) and right after 1972 (See Figure 2) the period is defined as searching for a new brand identity $[2,3]$. Sumerbank's aim was to develop industry, to educate working people mostly living in rural areas, to encourage the use of local products and to maintain the integration of urban and rural areas starting from 1930's. Along with the privatization process started in 1987, most of the factories were owned by the private sector. Unfortunately some of the settlements such as Izmir Halkapinar Basma Sanayii Müessesesi pillaged in the beginning 2000's, the equipments, machinery and the fabrics were demolished. Other settlements transferred to municipalities and universities. After the rapid change in economic and social conditions of the institution for the last thirty years, Sumerbank left behind a very important textile archive after ceased its production from 2000 's.

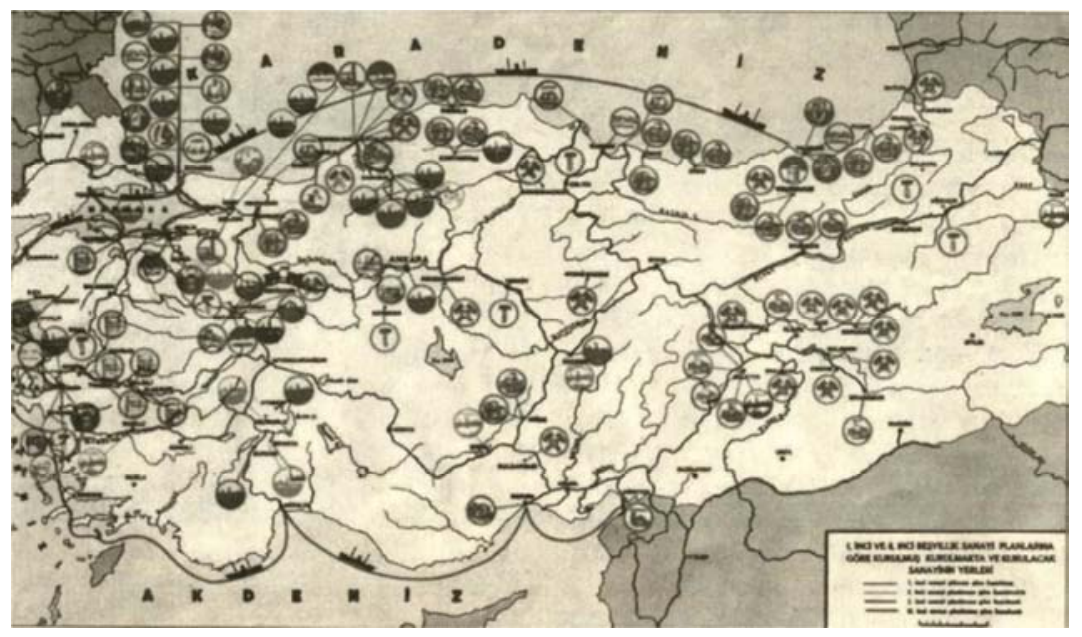

Figure 2. Map showing the Sümerbank factories (Tudita archive).

\subsection{Historical Overview on Sumerbank Culture}

In 1930, Sumerbank factories initially contributed to the nation-state building project by means of producing affordable textile products. In spite of their limited colour range due to the economic conditions, these fabrics led to the development of a national textile design style creating "a Sumerbank material culture in Turkey by introducing its own fabrics and distinctive designs". (See Figure 3).

Especially in the times of 1950s where a majority of population living in rural areas [3] in Turkey, Sumerbank fabrics was a chance and great opportunity for women sewing from western fashion magazines including new dress alternatives. These dress models also had become a significant part of the wardrobe of almost all women by means of their representation in national fashion shows and printed magazines. (See Figure 4). It is also known that, until 1970s, textile designers of Sumerbank used limited color range instead of flamboyantly colored printed fabrics considering the wartime conditions.

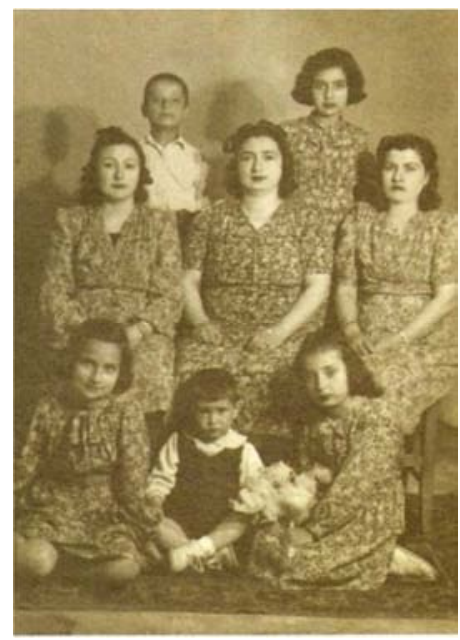

Figure 3. Flower patterned examples of Sümerbank calico dresses, 1944 (Çağla Ormanlar Ok archive). 


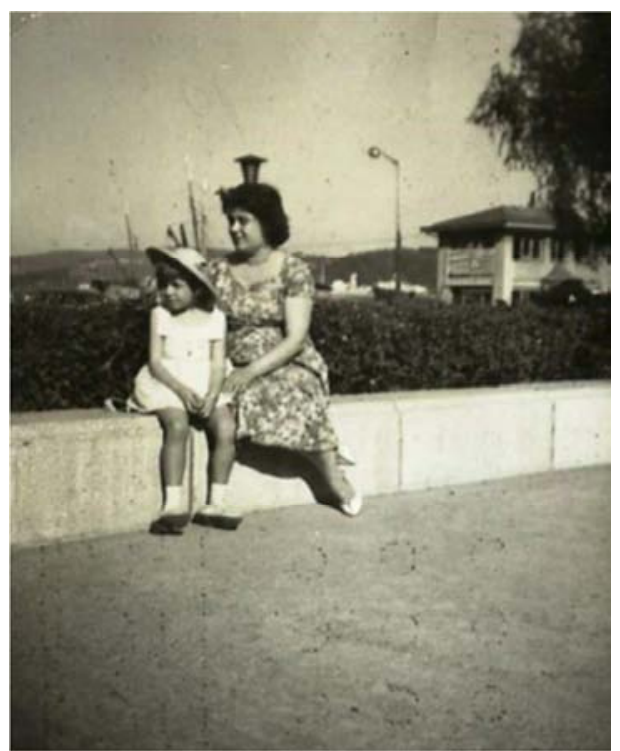

Figure 4. Sümerbank Style in 1950s (Elvan Özkavruk Adanır archive).

Sumerbank institutions and factories played significant economic, cultural and social roles in the modernization process of the Turkish Republic. Sumerbank Industrial Settlements, conceived as small factory towns, comprised not only production and support facilities (warehouses, workshops, boiler house, water tower, garage and fire station), but also residential (family houses, single houses and dormitories), social/cultural (cafeterias, social clubs, cinemas, guest houses and day-care centers), recreational (parks, swimming pools and sports fields) and educational (kindergartens and primary schools) facilities [4]. In this way, these settlements could be considered as 'cultural and social life long learning centers' for the workers, they learned the rules of good manners, how to dress as a modern Turkish citizen, they joined theather or opera clubs and had a chance of watching recent movies of that time.

\subsection{Patterns Produced by Sümerbank İzmir Halkapınar Basma Settlement}

Nazilli Printing Factory had been started production in October 9, 1937. During the Second World War, between 1942-1943 most of the textile workers of Kayseri and Nazilli factories had drafted into military service. Almost there was no one left and most of the weaving looms were of no use. In time, Sumerbank had been taken consideration of this situation and decided to carry some of the weaving looms to Izmir. The upper management decided to educate textile workers for İzmir Halkapınar Basma Settlement. The spinning and weaving departments founded in 1953, printing department founded in 1955. Starting from 1955, the factory esipecially produced calico and flannel fabrics until 2001. Addition to these typical fabrics, İzmir Halkapınar Basma Settlement also produced sateen, printed plaids, printed striped fabrics, mercerized home textiles, duvetin (divitin), muslin and pique (pike) fabrics. Sümerbank Halkapınar stopped its production after 2000s and left behind a very important textile archive. (See Figure 5).

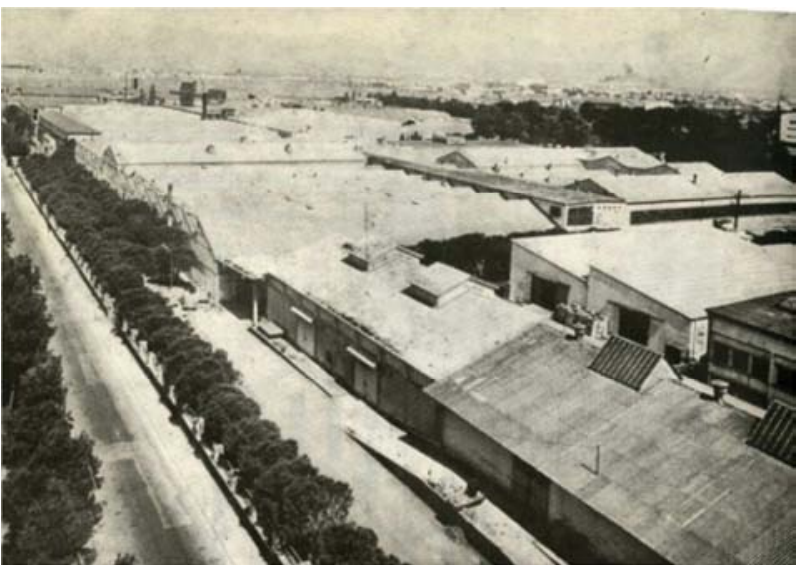

Figure 5. İzmir Basma Sanayi Settlement (Cumhuriyet'in 50. Yllinda Sümerbank, Genel Müdürlük Araştırma ve Planlama Müdürlügü Uzmanlarl, Genel Müdürlük İhtisas Şubeleri ve Iş̧letmeleri, Baskl: Araştırma ve Planlama Müdürlüğü ile Konjonktür ve Neşriyat Müdürlüğü, Tisa Matbaası, s.60).

\section{Research Method}

The textile archive of Sumerbank Halkapınar Basma Sanayi donated to the İzmir University of Economics, Faculty of Fine Arts and Design in 2006. Unfortunately the fabrics were in very bad condition and they were found in trash. It is so important for Turkish cultural heritage to preserve this archive. One of the best ways to transfer this knowledge to next generation is to create a digital archive. In that sense, developing a digital archive would provide solutions to these problems stated above. Under this statement, Sumerbank patterns found in Sumerbank İzmir Halkapınar Basma Settlement had been started to generate through new collaborative networks, as well as new types of digital media and cultural heritage services.

Sumerbank's encouraging attempts on using national products as a state centered institution, improvement policies on national economy and its precise situation in the Turkish textile history had been situated Sumerbank as a worthstressing value. Under that respect, the fabrics produced during the last 50 years (from 1959 to 2001) in Sumerbank Izmir Halkapınar Basma Sanayii Settlement have been digitally recorded and preserved under Sümerbank Digital Archive Project in 2015 which was supported by İzmir Development Agency (IZKA). It was difficult to build and expand the knowledge of cultural heritage due to limited literature and funding given to the research. This project was started under the name of Turkish Digital Textile ArchiveTUDITA and now it is available on the website named "tudita.ieu.edu.tr".

\subsection{Turkish Digital Textile Archive and Processes of the Project}

Cultural heritage does not only have a cultural, historical significance, but also represent a social value. Particularly with new technologies and the internet, digital museums have been having an increasing interest. The research methodology used in preparing Sumerbank Digital Textile 
Archive Project comprised documentation of in depth interviews with people once worked in Sumerbank factories as designers, managers or employers. Interviews were also conducted with several cultural heritage specialists and institutions and particularly digitizing and scanning of selected fabric swatches from the old fabric swatced books. The information collected and received from the interviews had been also used in the digital archive processes. General methods used in the project can be divided as;

1. Preservation and conservation of the fabric swatch books

2. Collecting data (survey studies, in-depth interviews, recordings, literature reviews)

3. Decision on selected textile patterns

4. Digitazing of patterns

5. Preparation of software program and website

6. Application of project activities (workshops, exhibitions, seminars)

Apart from that, ethical issues and copyright limitations had been considered out of these abundant case studies and research on Sümerbank textiles produced from İzmir Halkapınar Basma Settlement. Managing online engagement with heritage collections, documents, ensuring authenticity, organizing access to heritage objects, and carrying out selection and interpretation had been resulted in as ethical challenges in the website $[5,6]$.

The study is acquainted with the textile swatch books, which were once, belong to the Sümerbank İzmir Halkapınar Basma Sanayii Settlement. These swatch books were archived, restorated and stored in Izmir University of Economics, Faculty of Fine Arts and Design. In 2006 and 2007, academic staff conducted field researches in Halkapınar and Nazilli facilities of Sümerbank. The primary goal of these studies was to collect and preserve printed textiles and accessories, as well as fabric swatch books, books and chemicals, most of which had largely deteriorated after the privatization process of Sümerbank. From Sümerbank Halkapınar Basma Sanayii Settlement, there had been founded 7456 fabric swatch books, accessories, and printing equipments. These books were collected and cleaned. Each of them has approximately 30 different designs having different color variations. (See Figure 6).

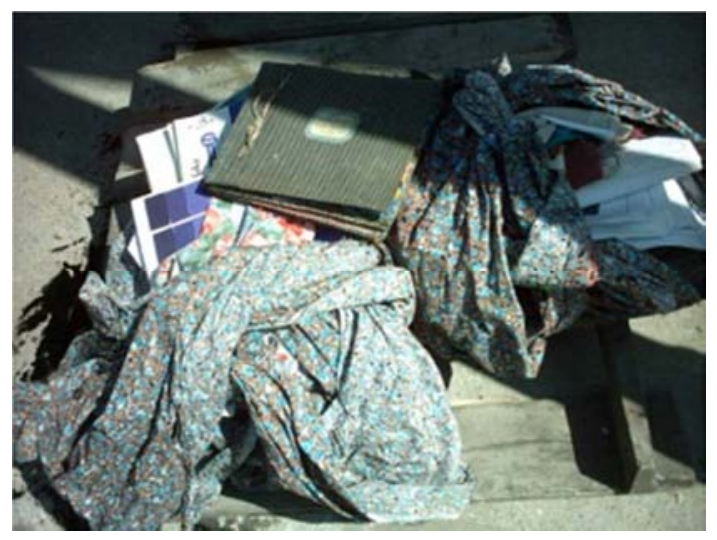

Figure 6. A photograph showing the Sümerbank textile albums before the conservation and classification (Dilek Himam, 2016).

\subsection{Documentation, Preservation and Conservation of Sümerbank Fabric Swatch Books}

Textile materials are sensitive to light, insects, physical stress, temperature, humidity and air pollution. In order to protect cotton textiles from the deterioration it is obligatory to store those in proper ways. Conservation and classification of the Sümerbank printed fabrics had been done by the university staff according to production years of the textiles. After collecting and conservation process of the swatch books, the materials were stored in the archive space in appropriate physical and ergonomic conditions. In the archive, functional storage spaces and documentation had been developed. Addition to that, passive conservation methods had been applied to textiles in order to prevent deterioration. (See Figure 7).

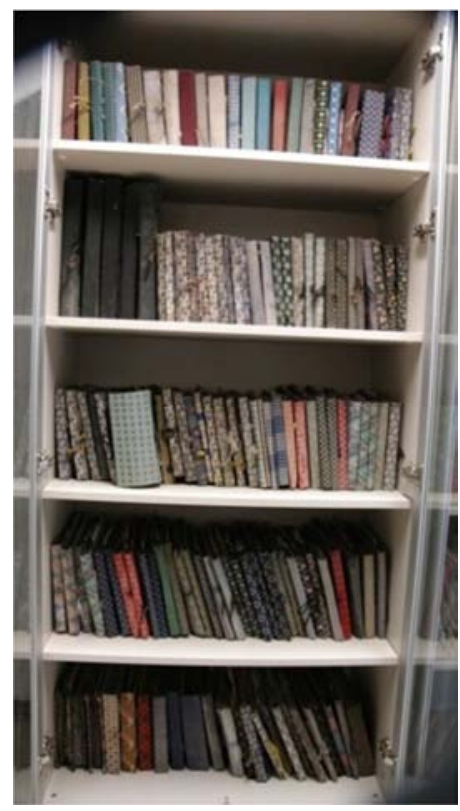

Figure 7. A photograph showing the Sümerbank textile albums after the conservation and classification (Dilek Himam, 2016).

Documentation of the archive, developing an appropriate system and physical conditions for the historical and cultural material was the first step of the archiving. During the documentation process, certain information forms had been used in order to record compositional and technical characteristics of the material.

\subsection{Digitalization of Sümerbank Fabric Swatch Books}

After this step of the project, in order to digitize and build the database, studies had been started to create a software program that supports to expand the database for further applications by collecting historical data and literature to build up a sustainable knowledge on historical textiles. After the documentation, designs, which are selected from the archive, had been scanned and defined considering certain parameters for the software program. After definition of the parameters, designs had been uploaded to the database (Figures 8, 9). 6600 fabrics had been scanned and digitized in this step of the project. 


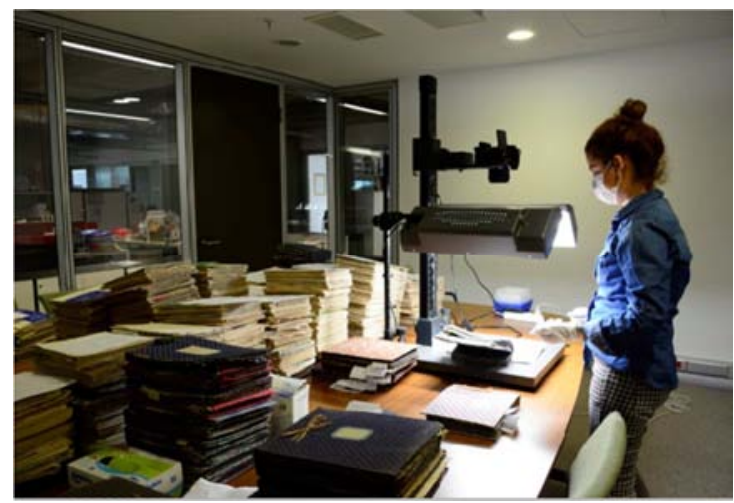

Figure 8. Digitalization of the albums (Ersan Çeliktaş, 2015).

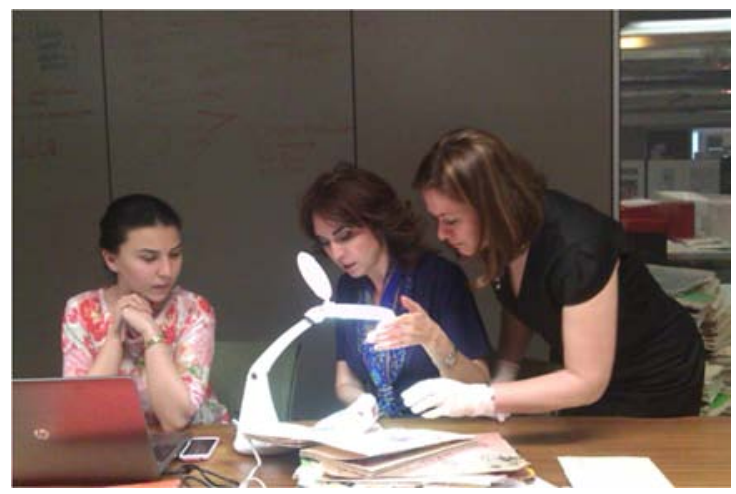

Figure 9. Analyzing technical properties of fabrics (Ersan Çeliktaş, 2015).

During the selection of the designs in the fabric swatch books, the most significant categories that were best defined the related period had been chosen by sampling method. Designs and patterns were grouped by using their numbers of variation, weaving techniques, materials, properties of printed patterns, production dates, and designer information if existed. Afterwards, designs were scanned in high resolution in order to prepare for the software program.

After the confirmation of number of variations, patterns were categorized under the subgroups such as flower patterns, stripes, conversational, geometric, animal prints etc. Designer informations of the patterns were seen after 1980s in the books. Unfortunately, it was not possible to reach the first generation of Sümerbank textile designers during the research. However some designers and people working in the Sümerbank factories in 1970s were helpful to fulfill the missing information about the Sümerbank fabrics and designs. During the project literature review, primary sources like photographs, family archives, letters and, written sources, in depth-interviews were the most frequently used methods. Apart from that, similar digital textile archives had also been studied among worldwide. While working on the system of TUDITA digital textile archive mobile applications, expertise of social media and communication age were considered for future generations, which also are applicable for further studies (See Figures 10, 11). Besides, the some of the replicas of patterns and fabrics had been re-produced by using a digital printing machine.

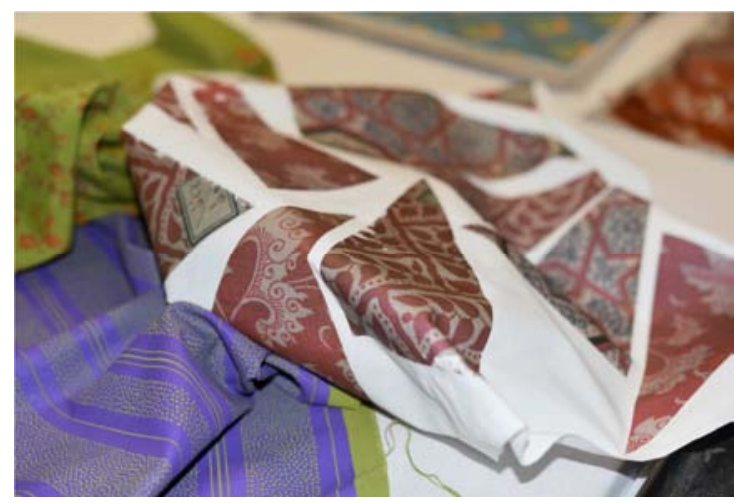

Figure 10. Some fabric samples from TUDİTA website (TUDİTA, 2015).
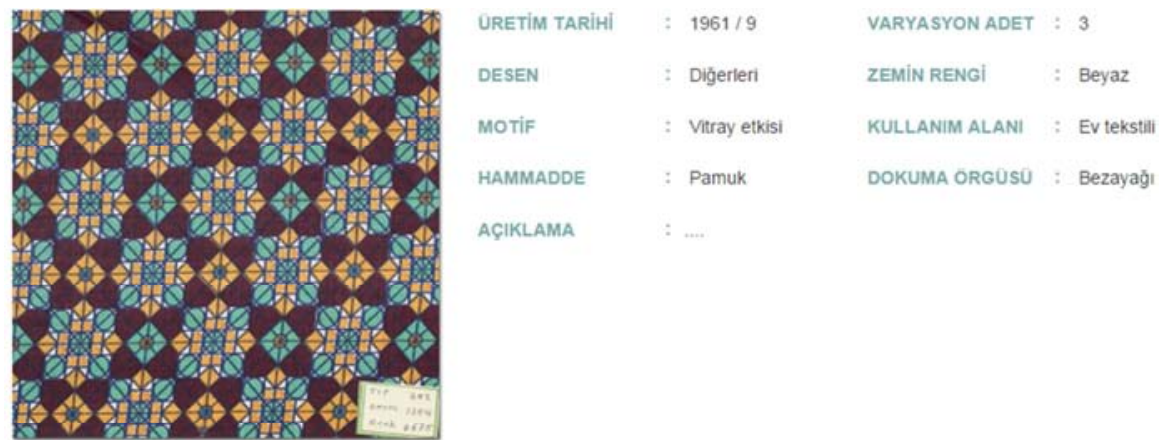

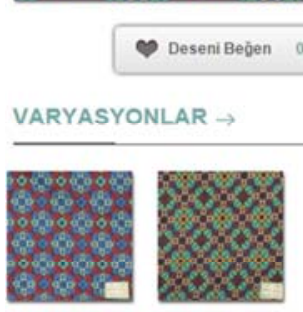

BENZER ÜRÜNLER $\rightarrow$

Figure 11. Data card sample of a Sümerbank pattern from TUDITA website, (TUDITA, 2015). 


\section{Outcomes of Project}

The fabrics, which are presented in this archive, are categorized according to their production dates, which are chronologically transferred to the digital platform as mentioned before. In general, there is a lack of information about the designers at Sümerbank; however, some designer names were discovered while examining the swatch books. During the selection process of fabrics, the aim was to select "typical" Sümerbank patterns. In the fabric swatch books, fabrics such as calico, flannel and poplin are mostly seen. There are also home textile and piqué fabric samples available. Special products such as printed fabric calendars, several flags, military prints, sheeting fabrics for state institutions etc. are also found in the archive [6].

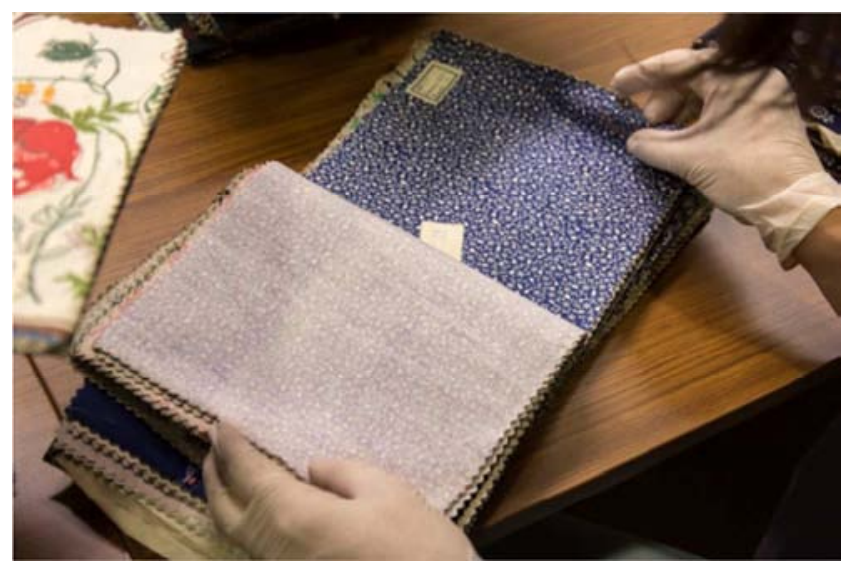

Figure 12. A page from the Sümerbank textile albums (Ersan Çeliktaş, 2015).

Fabrics selected in the archive are categorized in ten sections as floral and herbal, striped, plaid and gingham, ethnic and cultural, geometric, animal motifs, fruit and vegetable motifs, Polka dots, conversational and other patterns. These main groups are also divided into sub-groups (See Figure 12).

\subsection{Floral and Herbal Patterns}

Sümerbank considers floral and herbal patterns as one of the most popular patterns. They were used extensively in womenswear since the 1930s. Patterns composed of realistic flowers like sunflower, dahlia, lilium, tulip, gerbera daisy, iris, lily, water lily, hydrangea, chrysanthemum, pansies, wild flowers, rose, poppy, rose bud, carnation, daisy are most common among the 3000 floral and herbal patterns uploaded to digital archive. In addition to these flowers, stylized flower motifs also used. Flowers are sometimes used as singular entities, but sometimes accompanied with borders, cartouches, frames, buckets, and medallions. Baskets, flowerpots, vase, ribbons, cages, lattice and trellis are also notable objects used together with flowers. Herbal motifs are seen as branches, clover, trees, buds, cactus, wheat, cotton balls, thorns, and leaves in various sizes (See Figures 13, 14).

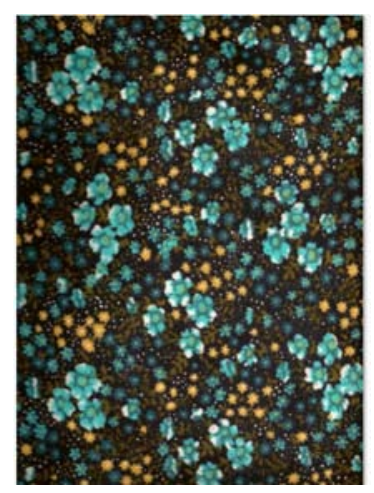

Figure 13. Typical flower patterned Sümerbank fabric (Tudita Archive).

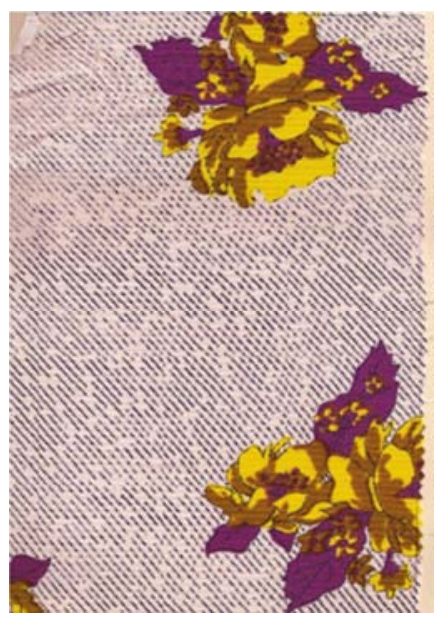

Figure 14. A flowered pattern Sümerbank fabric from 1970s (Tudita Archive).

\subsection{Striped Patterns}

Another important category is striped patterns. The typical striped Sümerbank pyjamas with their monochrome colours epitomized the unique Sümerbank striped pattern. Classic mono-coloured striped Sümerbank pyjamas are mainly found in a mahogani, blue and brown colour scheme. These pyjama patterns quickly became a classic and are symbolic for Turkish men. Striped pyjamas can be classified into seven groups as thick, thin, zigzag, curvilinear, dashed, diagonal and eccentric. In some examples, these groups were used together. There were 400 striped patterns selected for the digital archive among many of these categories.

\subsection{Plaids and Gingham Patterns}

Plaid and gingham patterns are other classic weaving patterns in the archive. However in order to lower the cost and increase the production, printed versions of these patterns were used. 50 gingham and 46 plaid patterns are selected from the digital archive which are timeless and popular patterns used by the public. Printed versions of these could be produced more quickly than the woven ones and there are many colour alternatives of this design. Their suitability for womenswear, menswear, childrenswear and home textiles is one the main reasons for the popularity of 
these patterns.

\subsection{Ethnical and Cultural Patterns}

The traces of Seljuk, Ottoman, Indian, Far Eastern, Africa and European cultures can also be seen in the ethnical/ cultural patterns located in the Sümerbank Halkapınar pattern archive. These fabrics, produced in accordance with the fashion trends of the period, are used for several purposes such as home textile and clothing. In an interview with Zekavet Bayer (Taş), one of the first designers at Sümerbank, she explains that Hikmet Sağun, who was a director at the Sümerbank factory in 1942, sent designers to Topkap1 Museum in İstanbul and mosques in Bursa to get inspiration. Their motto was "Design Turkish calico fabrics by using Turkish motifs". Turkish motifs and Anatolian flowers were revived in these Sümerbank fabrics [7].

\subsection{Geometric Patterns}

Geometric patterns found in Sümerbank Halkapınar pattern archive are not as popular as floral patterns but are also commonly used. In the digital textile archive there are 692 geometric patterns including motifs such as square, equilateral quadrangle, checkered, oval, circle, lozenge, rectangle, triangle, hexagon, rhomboid, octagon, hoop, half circle, quadrilateral, and dot. Selected geometric patterns in TUDITA website represent typical examples from the geometric pattern category.

\subsection{Polka Dots}

One of the most popular motifs among these groups is polka dots. These fabrics are desirable and essential materials for both fashion designers and women. It can be said that Polka dots are popular almost every decade in Europe and United States. The name Polka dot is derived from the Bohemian folk dance style, it is a classical spring pattern generally used as blue coloured motifs on white ground colour [10]. The motif is full. They can be printed regularly or dispersedly. In the digital archive, there are small, medium and large polka dots printed on fabrics. There are blue, green and pink coloured versions on both white and coloured backgrounds.

\subsection{Animal Motifs}

In the archive, animal motifs are categorized into three sub-groups. On the fabrics, this includes realistic animal drawings including motifs such as bear, rabbit, tiger, leopard, dog, pig, polar bear, cow and cock. Cartoon animals are mostly seen in childrenswear, babywear and sheeting fabrics. In these fabrics cats, chicks, sheep, ducks, bears, elephants, toucan, gazelles, crocodile, poultry, sharks, rabbits, dogs, penguins, butterflies, fish, birds, frogs and ladybugs are used in stylized way. Among these patterns, generally soft colours like light blue, light pink, light yellow are used for thin cotton fabrics for summer or flannel fabrics for winter. Another popular pattern group located under this group is prints of different animal skins such as zebra, tiger and leopard.

\subsection{Fruit and Vegetable Patterns}

Fabrics produced by using fruit and vegetable patterns are generally used for home textiles such as tablecloths, kitchen curtains and kitchen towels. In addition to that, they can also be used for clothing. Artichoke, nut, pinecone, apple, strawberry, lemon, pineapple, banana, carrot, grape, damson plum, pear, pepper are some of the motifs that could be found on these fabrics. These patterns are generally printed on a smooth ground colour with bright and vivid colours. In some examples, fruit motifs are used on striped or plaid grounds.

\subsection{Conversational Themes}

Group of conversational patterns can be defined as a group that has maximum variety of motifs among all pattern groups in the archive. Marine and sea themes are amongst the most popular themes, which also include sports, Olympic Games, and space themes, all reflecting worldwide fashion trends. Signs, symbols, letters, objects, star, cartoon characters, patchwork, heraldry, precious stones, toy games, mythology, balloons and bubbles, vehicles, buildings, houses, furniture, people, flash, landscape are other conversational patterns. There are also special fabrics produced for special days like holidays, New Year's Day, and Easter. In addition to these patterns heart shape, confetti, rope, gear wheel, bow and ribbons, basket weave and lace effect, labyrinth, camouflage, baby apron, map, circus, shirt, music, flags, zodiac, smiley, fan, hardware, baby, feather are other motifs found on the fabrics.

\subsection{Other Categories}

The patterns in this group cannot be classified in the main categories defined above. They include motifs such as drops, crescents, houndstooth prints, interlocking forms, marble, stained glass, and mosaic effects. Moreover, optic, airbrush effect, abstract, three-dimensional effect, watercolor effect and cellular forms are also among the motifs of this group. There are 612 different patterns loaded to the the digital pattern archive which are epresenting this group.

\section{Conclusion}

The digital textile archive of Sümerbank fabric designs are important and valuable source for researchers, related industries and students, not only to create an awareness of cultural heritage for contemporary fashion and design culture, but also for the enlightenment of Turkish textile printing history. Building a digital network covering the images of the textile archive [8], which provides an access to worldwide researchers, academics and students and the website, will not only provide the information and visual presentation of textile samples, but also ensure the visibility and sustainability of the project as the main promotional platform for the project. In conclusion, through a digital 
archive project, Sümerbank designs as a cultural heritage will raise a consciousness among Turkish entrepreneurs and designers of textile and fashion industry towards historical textiles as potential design sources to interpret into contemporary textiles and fashion in order to create an excitement to this collective memory for re-construction of design identity for being competitive in the international market. Respect to development of fashion and textile design culture in Turkey, the action will be assumed as a part of larger program of construction of Turkish contemporary design knowledge, culture and identity in an international level.

\section{Acknowledgements}

We would like to express our thanks to İzmir Development Agency (IZKA) and Izmir University of Economics for their support on this project and Sumerbank workers who shared their knowledge.

\section{References}

[1] D. Himam and B. Pasin, Designing a National Uniform (ity): The Culture of Sümerbank within the Context of the Turkish Nation-State Project, Journal of Design History, Special Issue: Uniforms in Design History: May 2011; Vol. 24, 2011, pp. 157-170.

[2] Z. Toprak, Sümerbank, Creative Yayıncılık, 1988.
[3] S. Bozdoğan, Modernism and Nation-Building: Turkish Architectural Culture in the Early Republic, University of Washington Press, 2001.

[4] F. Özbay, "Kadınların Ev İçi ve Ev Dışı Uğraşlarındaki Değişme", 1980 'ler Türkiye'sinde Kadın Bakış Açısından Kadınlar, Şirin Tekeli (ed.), İletişim Yayınları, İstanbul, 1995.

[5] D. Himam and B. Pasin (2011). Designing a National Uniform (ity): The Culture of Sümerbank within the Context of the Turkish Nation-State Project, Journal of Design History, Special Issue: Uniforms in Design History: May 2011; Vol. 24, pp. $157-170$.

[6] E. M. Corrado, Digital Preservation for Libraries, Archives, and Museums, Rowman \& Littlefield Publishers, 2017.

[7] Z. Manžuch (2017). Journal of Contemporary Archival Studies Volume 4 Governance of Digital Memories in the Era of Big Data Article 42017 Ethical Issues in Digitization of Cultural Heritage Vilnius University, http://elischolar.library.yale.edu/cgi/viewcontent.cgi?article=1 036\&context=jcas. (visit: 12.01.2017).

[8] E. Yazgan Bulgun, E. Özkavruk Adanır, F. Dilek Himam Er, Türkiye Bask1 Desenleri Tarihi: Sümerbank Örneği: 19562001, İzmir Kalkınma Ajans1 ve İzmir Ekonomi Üniversitesi Yayınları: İzmir, 2015.

[9] D. Özsüphandağ Yayman, A. Sönmez (2003), Desenleri Çeyrek Yüzyılın Kumaşına Sindi, İzmir Life, April, İzmir.

[10] J. Stewart, Patternalia: An Unconventional History of Polka Dots, Stripes, Plaid, Camouflage, \& Other Graphic Patterns, Bloomsbury, 2015. 